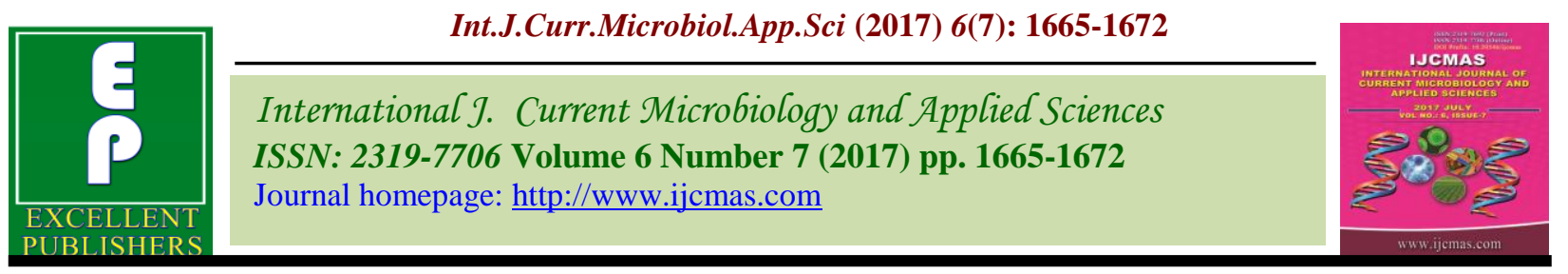

Original Research Article

https://doi.org/10.20546/ijcmas.2017.607.201

\title{
Impact of Different Tillage Practices with Weed Management Methods on Growth, Yield and Economics of Rice (Oryza sativa L.) in South Eastern Part of Bihar
}

\author{
P.K. Singh ${ }^{1 *}$, Manita Kumari ${ }^{2}$, Pradeep Prasad ${ }^{3}$ and Rajiv Nayan ${ }^{4}$ \\ ${ }^{1}$ Krishi Vigyan Kendra, Jamui (Bihar), India \\ ${ }^{2}$ Department of plant protection, T. D. College, Jaunpur (UP), India \\ ${ }^{3}$ Department of Agronomy, ${ }^{4}$ Department of Extension, SHUATS, Allahabad (UP), India \\ *Corresponding author
}

\section{A B S T R A C T}

A farmer's participatory trail was conducted during Kharif season of 2014 and 2015 on

\section{Keywords}

Zero tillage, Stale bed direct seeded rice, Mechanical transplanted rice, Conventional tillage,

Establishment method, Weed management, Herbicide.

Article Info

Accepted: 19 June 2017 Available Online: 10 July 2017 farmers' field at Kumar village (Sikandra) of Jamui district (Bihar) under CSISA project. The experiment was laid out in the factorial randomized block design using three way ANOVA table. The experiment consisted of four tillage practices viz. $\mathrm{T}_{1}$-Stale bed direct seeded rice, $\mathrm{T}_{2}$-ZT direct seeded rice, $\mathrm{T}_{3}$-Mechanical transplanted rice, $\mathrm{T}_{4}$-Conventional puddle transplanted rice and six weed management practices viz. $\mathrm{W}_{1}$-Weedy check (control), $\mathrm{W}_{2}$-Weed free, $\mathrm{W}_{3}$-Pyrazosulfuron at $20 \mathrm{~g} \mathrm{ha}^{-1}$ as pre emergence, $\mathrm{W}_{4}$-Oxadarzil at $18 \mathrm{~g}$ ai ha ${ }^{-1}$ as pre emergence, $\mathrm{W}_{5}$-Pyrazosulfuron at $20 \mathrm{~g} \mathrm{ha}^{-1}$ as pre emergence fb bispyribac sodium at $25 \mathrm{~g}^{\text {ai ha }}{ }^{-1}$ at 22 DAS and $\mathrm{W}_{6^{-}}$Oxadarzil at $18 \mathrm{~g}$ ai ha ${ }^{-1}$ as pre emergence fb bispyribac sodium at $25 \mathrm{~g}$ ai ha ${ }^{-1}$ at 22 DAS. Treatment $\mathrm{T}_{3}$ mechanically transplanted rice recorded highest plant height $(94.20 \mathrm{~cm})$, number of effective tillers (250.64), dry matter $\mathrm{m}^{-2}(1369.7 \mathrm{~g})$, length of panicle $(24.12 \mathrm{~cm})$, weight of panicle $(2.72$ g), no. of grains (115.47), test weight (25.62 g) grain and straw yield $3778 \mathrm{~kg}$ and $6105 \mathrm{~kg}$ $\mathrm{ha}^{-1}$ respectively. Lowest Weed density (26.34 and 6.02) and weed dry weight (3.03 and $6.04 \mathrm{~g})$ were recorded with stale bed direct seeded rice at 30 and 60 DAS. Under weed management practices lowest weed density (9.34 and 3.03) and weed dry weight $(0.88$ and $2.82 \mathrm{~g})$ at 30 and 60 DAS. Maximum Grain (3847 $\left.\mathrm{kg} \mathrm{ha}^{-1}\right)$ and Straw yield (6184 kg ha-1) was recorded under treatment $\mathrm{W}_{5}$ Pyrazosulfuron at $0.20 \mathrm{~kg} \mathrm{ha}^{-1}$ as pre emergence fb bispyribac sodium at $0.20 \mathrm{~kg}$ ai ha ${ }^{-1}$ at 22 DAS. The maximum net return was obtained with treatment $\mathrm{W}_{5}$ (Rs. 28,631) and B: C ratio of 2.05.

\section{Introduction}

Rice is one of the most important cereal crops and provides food security and livelihood for millions of people across the globe. It is the main staple food of India, covering an area of about $43.97 \mathrm{~m}$ ha with the total production and productivity of $104.32 \mathrm{mt}$ and $2.37 \mathrm{t} / \mathrm{ha}$ respectively during 2011-12 (Annonymous 2013 a). In India, rice plays an important role in the economy aswell as in rural livelihoods and is the staple food crop, second only to wheat. Major rice cultivation method used is manual transplanting of nursery grown seedlings into puddled soil. Puddling is a process of cultivating soil in standing water which consumes large amount of water. Moreover, as water resources are depleting 
due to intensive use of toxic pesticides and also resulting in scarcity of water in many part of the world, as there is competition between industrial and agricultural consumption of water resources (Mahajan et al., 2011, 2012). There is a great concern that Indian rice growers will probably have inadequate access to irrigation water in the future (Mahajan et al., 2013). Hence, shortage of irrigation water, threatens the sustainability of rice production in irrigated conditions (Chauhan et al., 2012, 2014). Rice is mainly cultivated in 38 district of Bihar. Out of this 25 districts are falling under low productivity group which accounts for $63 \%$ of 36.57 lakh hectares of total area under rice in the state. Rice is one of the major crops of Bihar but its productivity is very poor. More than $60 \%$ rice area is concentrated in Bihar in low productivity zone and this zone contributes more than $50 \%$ of rice production of the state. Area coverage under rice with high yielding varieties is about $65 \%$ and irrigation facility is available for about $40 \%$ rice area in the state, if the productivity of low productivity zone is increased, the rice production can be increased considerably without increasing the area under rice. Transplanting is the major method of rice cultivation in Bihar. However, transplanting is becoming increasingly difficult due to shortage and high cost of labour, scarcity of water, uneven distribution of rainfall and less profit. The transplanting of rice under puddle conditions requires more irrigation water and creates a hard pan below the surface. The conventional tillage, puddling and long duration varieties further delay the transplanting of rice. Direct seeding and mechanically transplanted rice have gained significance to reduce the cost of production, saving of water, fuel, energy, time and wear and tear of tractor, which can be achieved by omitting the repeated tillage operations for land preparation. Directedseeded rice (DSR) needs only $34 \%$ of the total labour requirement and saves $27 \%$ of the total cost of transplanted crop (Mishra and Singh, 2011). Herbicide (pendimethalin@1.00 kg ai $\mathrm{ha}^{-1}$ ) as pre-emergence supplemented with two hand weedings were needed to reduce weed growth in zero till dry-seeded rice (Singh et al., 2005a). Tillage influences weed infestation, as under zero tillage seeds of most of the seasonal weeds remain on the soil surface, while under conventional tillage the weed seeds are inverted by plough and buried beneath the soil, thus under zero tillage the infestation of weeds are more. However, the crop establishment under zero tillage in ricewheat system is gaining momentum in recent days as a pathway to address rising water and labour scarcity, increasing cost of fuel energy and to enhance resource-use efficiency and system sustainability. Zero tillage sowing in standing crop resides along with application of herbicides in proper combination or sequence leads to lower weed population and higher yield than conventional planting (Sharma and Singh, 2012). However, direct seeded rice is subjected to greater weed competition than transplanted rice. Weeds offer intense competition with the rice crop for all critical growth factors, viz. space, sunlight, water and nutrients, thus considerable yield loss. Manna (1991) reported a yield reduction of $25 \%$ in transplanted rice, $32 \%$ in puddle broadcasted rice and $52 \%$ in direct seeded rice due to weeds. Direct seeded rice (DSR) has the potential of saving water through earlier establishment of plants and thus it facilities early seeding of wheat in rice-wheat cropping system (Ladha et al., 2003). Zero tillage or reduce tillage establishment is used widely for many crops around the world and this technology has potential to allow saving in time, energy, water and labour during rice establishment (Piggin et al., 2002). There are some limiting factors associated with DSR that impair yields including crop-weed competition. Compared to transplanted rice, the yield losses in DSR is greater due to 
absence of flooding water at the early stage of the crop to suppress weed growth (Singh et $a l ., 2007)$. Aerobic rice is the most promising one in terms of water saving (Anwar et al., 2010). In precise, aerobic rice system refers to growing direct seeded rice on non-puddled aerobic soil without standing water (Bouman 2003) and rice is managed intensively as an upland crop like wheat or maize. Aerobic rice is either rainfed or irrigated and soil water is maintained around field capacity in the root zone. This system eliminates surface runoff percolation and evaporation losses (Singh and Chinnusamy 2006) resulting in twice the water productivity of flood irrigated rice (Bouman et al., 2002). Industrialization also threatens rice production due to migration of rural labour to cities in search of job, which causes shortage of manual labour during the peak period of rice cultivation. This, results in late transplanting, less acreage under rice, low yield and delay in planting of the next crop. Therefore the objective of this study was to evaluate the best method of rice establishment and weed control method in DSR.

\section{Materials and Methods}

Adaptive research trail were conducted for two years in 2014 and 2015 in kharif season at Kumar (Sikandara) village of Jamui district (Bihar) under Cereal System Initiative for South Asia (CSISA) project. The research site soil was sandy loam having 50\% sand, 30\% silt and $14.4 \%$ clay. The soil contained $0.66 \%$ organic carbon, $182.5 \mathrm{~kg} \mathrm{ha}^{-1}$ of available nitrogen, $29 \mathrm{~kg} \mathrm{ha}^{-1}$ of available Phosphorus and $160 \mathrm{~kg} \mathrm{ha}^{-1}$ of available Potassium with pH 7.2 in the year of experiment. The experiment was laid out in RBD (Factorial) with treatment comprising four sowing methods viz. $\mathrm{T}_{1}$ - Stale bed direct seeded rice (STDSR), $\mathrm{T}_{2}-$ Zero tillage direct seeded rice (ZTDSR), $\mathrm{T}_{3}$ Mechanical transplanted Rice (MTPR) and $\mathrm{T}_{4}$ conventional tillage (CT) and six different weed control methods viz. $\mathrm{W}_{1}$ -
Weedy check (control), $\mathrm{W}_{2}-$ Weed free, $\mathrm{W}_{3}$ Pyrazosulfuron at $20 \mathrm{~g} \mathrm{ha}^{-1}$ as pre emergence, $\mathrm{W}_{4}$ - Oxadarzil at $18 \mathrm{~g}$ ai $\mathrm{ha}^{-1}$ as pre emergence, $\mathrm{W}_{5}$ - Pyrazosulfuron at $20 \mathrm{~g} \mathrm{ha}^{-1}$ as pre emergence followed by bispyribac sodium at $25 \mathrm{~g}$ ai $\mathrm{ha}^{-1}$ at $22 \mathrm{DAS}, \mathrm{W}_{6}$ Oxadarzil at $18 \mathrm{~g}$ ai $\mathrm{ha}^{-1}$ as pre emergence followed by bispyribac sodium at $25 \mathrm{~g}$ ai $\mathrm{ha}^{-1}$ at 22 DAS. Rice variety MTU 7029 were sown under STDSR and ZTDSR on $20^{\text {th }}$ June 2014 and $22^{\text {th }}$ June 2015 respectively, where as in MTPR and CT nursery was done on same day. 18 days old seedling was transplanted under MTPR in unpuddled condition whereas in CT method 25 days old seedling was manually transplanted in puddle condition. In SDSR pre - plant herbicide glyphosate at $1.00 \mathrm{~kg}$ ai ha ${ }^{-1}$ was sprayed two times $\mathrm{I}^{\text {st }}$ at one month before and second time seven days before of sowing in proper moisture and rice was sown through zero tillage machine keeping rows $20 \mathrm{~cm}$. apart without any tillage operations. Pre - plant herbicide glyphosate at $1.00 \mathrm{~kg}$ ai ha ${ }^{-1}$ was sprayed one week before sowing in ZTDSR at proper moisture in the soil and seed was sown through zero tillage keeping rows $20 \mathrm{~cm}$. apart without any tillage practices. In MTPR rice nursery prepared on mat and 18 days old nursery was transplanted through rice transplanter. Whereas, in conventional tillage field was ploughed through mould board plough followed by cultivator and planking was done after each ploughing and puddling was done in standing water. Seed rate $30 \mathrm{~kg}$ $\mathrm{ha}^{-1}$ was used in all treatments except conventional tillage. Whereas, in conventional tillage $50 \mathrm{~kg} \mathrm{ha}^{-1}$ seed rate was used. In weed management treatments Preemergence herbicide pendamethalin at $1.5 \mathrm{~kg}$, Pyrazosulfuron at $20 \mathrm{~g}$ and Oxadarzil at $18 \mathrm{~g}$ ai ha ${ }^{-1}$ were applied as pre emergence within 48 hours of sowing. Whereas, Post emergence herbicide bispyribac sodium at 25 $\mathrm{g}$ ai $\mathrm{ha}^{-1}$ as tank mixture was sprayed at 22 days after sowing in rice as per treatment 
required. Under weed free treatment four weeding was done at different intervals of crop. The crop was fertilized with recommended $110 \mathrm{~kg} \mathrm{~N}+50 \mathrm{~kg} \mathrm{P}_{2} \mathrm{O}_{5}+50 \mathrm{~kg}$ $\mathrm{K}_{2} \mathrm{O}$ was applied in the form of urea, DAP and MOP respectively.

Full dose of the phosphorus and potash and half nitrogen were applied at the time of seeding. Remaining nitrogen was applied in two equal splits at mid tillering and panicle initiation stage. Data were recorded from an area enclosed in quadrate of $0.25 \mathrm{~m}^{2}$ randomly selected at three places in each plot. Herbicidal spray was done with knapsack sprayer fitted with flat fan nozzle using 500 litres of water $\mathrm{ha}^{-1}$. Other packages of practices rather than treatments were followed as per recommendation for rice crop.

\section{Results and Discussion}

A perusal of the pool data (Table 1) clearly shows that there was significant difference among different tillage practices on weed density and weed dry weight at 30 and 60 DAS. Minimu weed density at 30 and 60 DAS was recorded in treatment $T_{3}$ (Mechanical transplanted Rice) as $90.60 \mathrm{~g}$ and $6.02 \mathrm{~g}$ followed by treatment $\mathrm{T}_{2}$ (ZTDSR).

Similarly weed dry weight also recorded minimum pooled values as $2.24 \mathrm{~g}$ and $6.04 \mathrm{~g}$ at 30 and $60 \mathrm{DAS}$ in treatment $\mathrm{T}_{3}$ which was closely followed by treatment $\mathrm{T}_{2}$ and were far superior to treatment $\mathrm{T}_{4}(\mathrm{CT})$ which recorded weed density (259.57 and 117.20) and weed dry weight (46.36 g and $107.13 \mathrm{~g}$ ) at 30 and 60 DAS respectively. This may be due to nondisturbance of soil in mechanical transplanting which did not allowed the weed seeds to come at the surface an emerge.

Herbicide treatment also showed significant variation with respect to weed density and weed dry weight at 30 and 60 DAS. Minimum weed density (9.34 and 3.04) was recorded in treatment $\mathrm{W}_{5}$ (pyrazosulfuron at $20 \mathrm{~g} \mathrm{ha}^{-1}$ as pre - emergence $\mathrm{fb}$ bispyribac sodium at $25 \mathrm{~g}$ ai $\mathrm{ha}^{-1}$ at $22 \mathrm{DAS}$ ) at 30 and 60 DAS respectively followed by treatment $\mathrm{W}_{6}$ (Oxadarzil at $18 \mathrm{~g}$ ai $\mathrm{ha}^{-1}$ as pre emergence $\mathrm{fb}$ bispyribac sodium at $25 \mathrm{~g}^{\text {ai ha }}{ }^{-1}$ at $22 \mathrm{DAS}$ ). The pooled data also revolved that at 60 DAS weed density recorded under treatment $\mathrm{W}_{6}$ $(3.04 \mathrm{~g})$ was found to be at par to that recorded under treatment $\mathrm{W}_{5}(3.38 \mathrm{~g})$. Similarly pooled values on weeds dry weight at 30 and 60 DAS also showed significant variation.

Minimum weed dry weight $(0.88 \mathrm{~g}$ and 2.63 g) was recorded in treatment $\mathrm{W}_{5}$ at 30 and 60 DAS respectively and was closely followed by treatment $\mathrm{W}_{6}$ which recorded weed dry weight (1.05 g and $2.82 \mathrm{~g})$ at 30 and 60 DAS and was found to be at par to treatment $\mathrm{W}_{5}$ this may be due to these herbicides belong to sulfonyl urease group which do not allow or rather kill the emerging weeds and the weed which escape from pyrazosulfuron are killed by bispyribac sodium which is applied 22 DAS. The other reason may be due to the fact that these herbicides are protein inhibitors thus not allowing the weed plants to synthesis protein and hence are killed.

The pooled data of table 2 revealed that tillage practices had significant effect on growth parameters of rice at panicle initiation stage. Maximum values of growth attributes viz. plant height $(94.20 \mathrm{~cm})$, no. of effective tillers $\left(250.64 \mathrm{~m}^{-2}\right)$, dry matter $\left(1396.70 \mathrm{~g} \mathrm{~m}^{-2}\right)$, length of panicle $(24.12 \mathrm{~cm})$, weight of panicle $(2.72 \mathrm{~g})$, no. of grains panicle ${ }^{-1}$ (115.47) and test weight $(25.62 \mathrm{~g})$ was recorded in treatment $\mathrm{T}_{3}$ (MTPR) followed by treatment $\mathrm{T}_{2}$ (ZTDSR) which was found to be at par to treatment $\mathrm{T}_{3}$ (Gangwar et al., 2005). This may be due to the fact that in MTPR only 16 days old seedlings are transplanted with soil attached to their roots which escapes transplanting shock as CT method rice. 
Table.1 Impact of different tillage practices with weed management on weed density and Weed dry weight in rice crop (pooled data of 2 years)

\begin{tabular}{|c|c|c|c|c|c|c|c|}
\hline Treatments & \multicolumn{2}{|c|}{$\begin{array}{l}\text { Weed Density at } 30 \\
\text { DAS No. }\end{array}$} & \multicolumn{2}{|c|}{$\begin{array}{l}\text { Weed Dry wt. at } \\
30 \text { DAS }(\mathrm{g})\end{array}$} & \multicolumn{2}{|c|}{$\begin{array}{l}\text { Weed Density at } \\
60 \text { DAS No. }\end{array}$} & $\begin{array}{l}\text { Weed Dry wt. at } \\
60 \text { DAS (g) }\end{array}$ \\
\hline \multicolumn{8}{|l|}{ Tillage (T) } \\
\hline $\mathrm{T}_{1}$-Stale bed direct seeded rice & \multicolumn{2}{|c|}{23.64} & \multicolumn{2}{|r|}{3.03} & \multicolumn{2}{|r|}{6.02} & 6.04 \\
\hline $\mathrm{T}_{2} \mathrm{ZT}$ direct seeded rice & \multicolumn{2}{|c|}{19.60} & \multicolumn{2}{|r|}{2,24} & \multicolumn{2}{|r|}{9.38} & 9.86 \\
\hline $\mathrm{T}_{3}$-Mechanical transplanted rice & \multicolumn{2}{|c|}{38.91} & \multicolumn{2}{|c|}{6.01} & \multicolumn{2}{|r|}{19.38} & 15.74 \\
\hline $\mathrm{T}_{4}$-Conventional puddle transplanted rice & \multicolumn{2}{|c|}{259.57} & \multicolumn{2}{|c|}{46.36} & \multicolumn{2}{|r|}{117.20} & 107.13 \\
\hline F-test & \multicolumn{2}{|c|}{$\mathrm{S}$} & \multicolumn{2}{|c|}{$\mathrm{S}$} & \multicolumn{2}{|r|}{$\mathrm{S}$} & $\mathrm{S}$ \\
\hline S.Ed. $( \pm)$ & \multicolumn{2}{|c|}{0.34} & \multicolumn{2}{|r|}{0.13} & \multicolumn{2}{|r|}{0.16} & 0.21 \\
\hline $\mathrm{CD}(\mathrm{P}=0.05)$ & & & & 0.59 & & 0.70 & 0.91 \\
\hline \multicolumn{8}{|l|}{ Herbicide (W) } \\
\hline \multicolumn{2}{|l|}{ Treatments } & \multicolumn{2}{|c|}{$\begin{array}{l}\text { Weed Density } \\
\text { at } 30 \text { DAS No. }\end{array}$} & \multicolumn{2}{|c|}{$\begin{array}{l}\text { Weed Dry wt. } \\
\text { at } \\
30 \text { DAS }(\mathrm{g})\end{array}$} & $\begin{array}{l}\text { Weed } \\
\text { Density at } 60 \\
\text { DAS No. }\end{array}$ & $\begin{array}{l}\text { Weed Dry } \\
\text { wt. at } \\
60 \text { DAS (g) }\end{array}$ \\
\hline \multicolumn{2}{|l|}{$\mathrm{W}_{1}$-Weedy check (control) } & \multicolumn{2}{|c|}{262.40} & \multicolumn{2}{|c|}{46.65} & 118.10 & 107.00 \\
\hline \multicolumn{2}{|c|}{$\mathrm{W}_{2}$-Weed free } & \multicolumn{2}{|c|}{0} & \multicolumn{2}{|c|}{0} & 0 & 0 \\
\hline \multicolumn{2}{|c|}{$\mathrm{W}_{3}$-Pyrazosulfuron at $20 \mathrm{~g} \mathrm{ha}^{-1}$ as pre- emergence } & \multirow{2}{*}{\multicolumn{2}{|c|}{$\begin{array}{l}23.75 \\
29.75\end{array}$}} & 3.10 & & 3.98 & 4.31 \\
\hline $\mathrm{W}_{4}$-Oxadarzil at $18 \mathrm{~g}$ ai ha ${ }^{-1}$ as pre- emer & & & & 4,14 & & 5.20 & 5.52 \\
\hline $\begin{array}{l}\mathrm{W}_{5} \text { - Pyrazosulfuron at } 20 \mathrm{~g} \mathrm{ha}^{-1} \text { as pre em } \\
\text { bispyribac sodium at } 25 \mathrm{~g} \text { ai ha }{ }^{-1} \text { at } 22 \mathrm{DA}\end{array}$ & gence fb & & & 0.88 & & 3.04 & 2.63 \\
\hline $\begin{array}{l}\mathrm{W}_{6} \text { - Oxadarzil at } 18 \mathrm{~g} \text { ai ha } \\
\text { bispyribac sodium at } 25 \mathrm{~g} \mathrm{ai} \mathrm{ha}^{-1} \text { at } 22 \mathrm{DA}\end{array}$ & ice fb & & & 1.05 & & 3.38 & 2.82 \\
\hline F-test & & & & $\mathrm{S}$ & & $\mathrm{S}$ & $\mathrm{S}$ \\
\hline S.Ed. $( \pm)$ & & & & 0.13 & & 0.08 & 0.19 \\
\hline $\mathrm{CD}(\mathrm{P}=0.05)$ & & & & 0.52 & & 0.35 & 0.74 \\
\hline
\end{tabular}

Table.2 Impact of different tillage practices with weed management on Growth attributes of rice (pooled data of 2 years)

\begin{tabular}{|c|c|c|c|c|c|c|c|}
\hline Treatments & $\begin{array}{l}\text { Plant } \\
\text { height } \\
(\mathrm{cm})\end{array}$ & $\begin{array}{c}\text { No. of } \\
\text { effective } \\
\text { tillers } \mathrm{m}^{-2}\end{array}$ & $\begin{array}{c}\text { Dry } \\
\text { matter } \\
\mathrm{m}^{-2}\end{array}$ & $\begin{array}{l}\text { Length of } \\
\text { Panicle } \\
(\mathrm{cm})\end{array}$ & $\begin{array}{l}\text { Weight of } \\
\text { panicle } \\
(\mathrm{g})\end{array}$ & $\begin{array}{c}\text { No. of } \\
\text { grains } \\
\text { panicle }\end{array}$ & $\begin{array}{c}\text { Test } \\
\text { weight } \\
(\mathrm{g})\end{array}$ \\
\hline \multicolumn{8}{|l|}{ Tillage practices $(\mathbf{T})$} \\
\hline $\mathrm{T}_{1}-$ Stale bed Direct Seeded Rice & 92.30 & 241.00 & 1344.5 & 22.00 & 2.48 & 108.38 & 25.60 \\
\hline $\mathrm{T}_{2}$-Zero Tillage Direct Seeded Rice & 92.0 & 233.50 & 1302.7 & 21.20 & 2.39 & 111.11 & 24.46 \\
\hline $\mathrm{T}_{3}-$ Mechanical Transplanted Rice & 94.20 & 250.64 & 1396.7 & 24.12 & 2.72 & 115.47 & 25.62 \\
\hline $\mathrm{T}_{4}-$ Conventional Rice & 73.40 & 182.65 & 1110.3 & 19.60 & 1.89 & 99.14 & 22.00 \\
\hline F-test & $\mathrm{S}$ & $\mathrm{S}$ & $\mathrm{S}$ & $\mathrm{S}$ & $\mathrm{S}$ & $\mathrm{S}$ & $\mathrm{S}$ \\
\hline S.Ed. $( \pm)$ & 0.79 & 0.63 & 18.25 & 0.07 & 0.07 & 1.02 & 1.38 \\
\hline C.D. at $5 \%$ & 3.36 & 2.70 & 77.29 & 0.28 & 0.30 & 4.35 & 0.31 \\
\hline \multicolumn{8}{|l|}{ Herbicides (W) } \\
\hline $\mathrm{W}_{1}$-Weedy check (control) & 72.85 & 180.85 & 1108.4 & 19.45 & 1.82 & 69.64 & 22.20 \\
\hline $\mathrm{W}_{2}$-Weed free & 99.80 & 265.4 & 1480.5 & 25.78 & 2.85 & 125.53 & 25.70 \\
\hline $\mathrm{W}_{3}$-Pyrazosulfuron at $20 \mathrm{~g} \mathrm{ha}^{-1}$ as pre- emergence & 88.52 & 230.5 & 1265.4 & 21.70 & 2.30 & 123.34 & 24.00 \\
\hline $\mathrm{W}_{4}$-Oxadarzil at $18 \mathrm{~g} \mathrm{ha}^{-1}$ as pre- emergence & 80.5 & 218.7 & 1205.6 & 21.00 & 2.17 & 105.65 & 23.85 \\
\hline $\begin{array}{l}\mathrm{W}_{5} \text { - Pyrazosulfuron } 20 \mathrm{~g} \mathrm{ha}^{-1} \text { as pre- emergence } \\
\text { fb bispyribac sodium at } 25 \mathrm{~g} \mathrm{ha}^{-1} \text { at } 22 \text { DAS }\end{array}$ & 93.5 & 244.65 & 1370.0 & 24.85 & 2.68 & 115.34 & 25.68 \\
\hline $\begin{array}{l}\mathrm{W}_{6} \text { - Oxadarzil at } 18 \mathrm{~g} \mathrm{ha}^{-1} \text { as pre emergence } \mathrm{fb} \\
\text { bispyribac sodium } 25 \mathrm{~g} \mathrm{ha}^{-1} \text { at } 22 \text { DAS }\end{array}$ & 91.0 & 238.4 & 1303.2 & 22.50 & 2.50 & 113.21 & 25.60 \\
\hline F-test & $\mathrm{S}$ & $\mathrm{S}$ & $\mathrm{S}$ & $\mathbf{S}$ & $\mathrm{S}$ & $\mathrm{S}$ & $\mathrm{S}$ \\
\hline S.Ed. $( \pm)$ & 0.68 & 0.70 & 0.60 & 0.25 & 0.04 & 0.49 & 0.28 \\
\hline C.D. at $5 \%$ & 2.65 & 2.73 & 2.35 & 0.96 & 0.18 & 1.90 & 1.08 \\
\hline
\end{tabular}


Table.3 Impact of different tillage practices with weed management on Yield attributes and economics of rice (pooled data of 2 years)

\begin{tabular}{|c|c|c|c|c|c|c|}
\hline Treatments & $\begin{array}{l}\text { Grain yield } \\
\left(\text { Kgha }^{-1}\right)\end{array}$ & $\begin{array}{l}\text { Straw yield } \\
\left(\mathrm{kg} \mathrm{ha}^{-1}\right)\end{array}$ & $\begin{array}{l}\text { Cost of } \\
\text { cultivation } \\
\left(\text { Rs. ha }{ }^{-1}\right)\end{array}$ & $\begin{array}{l}\text { Gross return } \\
\left(\text { Rs. ha }^{-1}\right)\end{array}$ & $\begin{array}{l}\text { Net } \\
\text { return Rs. } \\
\text { ha }^{-1}\end{array}$ & $\begin{array}{l}\mathrm{B}: \mathrm{C} \\
\text { ratio }\end{array}$ \\
\hline \multicolumn{7}{|l|}{ Tillage practices $(\mathbf{T})$} \\
\hline $\mathrm{T}_{1}-$ Stale bed Direct Seeded Rice & 3503 & 6004 & 27,517 & 50,793 & 23,276 & 1.84 \\
\hline $\mathrm{T}_{2}$-Zero Tillage Direct Seeded Rice & 3457 & 5813 & 26,500 & 50,126 & 23,626 & 1.89 \\
\hline $\mathrm{T}_{3}-$ Mechanical Transplanted Rice & 3778 & 6105 & 27,500 & 53,331 & 25,831 & 1.93 \\
\hline $\mathrm{T}_{4}-$ Conventional Rice & 3114 & 5367 & 32,425 & 45,153 & 12,728 & 1.39 \\
\hline F-test & $\mathrm{S}$ & $\mathrm{S}$ & & & & \\
\hline S.Ed. $( \pm)$ & 1.04 & 0.87 & & & & \\
\hline C.D. at $5 \%$ & 4.43 & 3.71 & & & & \\
\hline \multicolumn{7}{|l|}{ Herbicides (W) } \\
\hline $\mathrm{W}_{1}$-Weedy check (control); & 2451 & 4453 & 30,225 & 35,539 & 5,314 & 1.17 \\
\hline $\mathrm{W}_{2}$-Weed free & 3910 & 6243 & 39,400 & 56,695 & 16,755 & 1.43 \\
\hline $\begin{array}{l}\mathrm{W}_{3} \text {-Pyrazosulfuron at } 20 \mathrm{~g} \mathrm{ha}^{-1} \text { as pre } \\
\text { emergence }\end{array}$ & 3559 & 6032 & 26,000 & 51,605 & 25,605 & 1.94 \\
\hline $\begin{array}{l}\mathrm{W}_{4} \text {-Oxadarzil at } 18 \mathrm{~g} \text { ai ha } \\
\text { emergence }\end{array}$ & 3380 & 5832 & 26,350 & 49,010 & 22,660 & 1.85 \\
\hline $\begin{array}{l}\mathrm{W}_{5} \text { - Pyrazosulfuron at } 20 \mathrm{~g} \mathrm{ha}^{-1} \text { as pre- } \\
\text { emergence fb bispyribac sodium at } 20 \mathrm{~g} \text { ai ha } \\
{ }^{1} \text { at } 22 \text { DAS }\end{array}$ & 3847 & 6184 & 27,150 & $55,781.5$ & 28,631 & 2.05 \\
\hline $\begin{array}{l}\mathrm{W}_{6}-\text { Oxadarzil at } 18 \mathrm{~g} \text { ai ha } \\
\text { emergence fb bispyribac sodium at } 25 \mathrm{~g} \text { ai ha } \\
1 \text { at } 22 \text { DAS }\end{array}$ & 3694 & 6048 & 27,350 & 53,563 & 24563 & 1.96 \\
\hline F-test & $\mathrm{S}$ & $\mathrm{S}$ & & & & \\
\hline S.Ed. $( \pm)$ & 7.74 & 4.42 & & & & \\
\hline C.D. at $5 \%$ & 29.51 & 1.63 & & & & \\
\hline
\end{tabular}

Mechanically transplanted rice results in early maturity and short the crop duration that transplanted rice (Gill 2008). The other reason for higher growth parameter in MTPR is that the seedlings are transplanted in un puddle condition with proper spacing and depth and there is less competition among plants for sun light, nutrients and moisture (Singh and Singh 1993, Gill et al., 2006).

In direct seeded rice there is saving of water, input, energy and time due un puddle condition, less manual labour required and use of machines (Zero tillage and Rice transplanter). Chauhan and Opena (2012) reported that puddling in transplanted rice system consumes up to $30 \%$ of the total rice water required. Similar result was also reported by Sharma et al., (2002) and Singh et al., (2002) that input water saving of $35-57 \%$ have been reported for dry direct seeded rice sown in to non-puddled soil compared with conventional method. The third reason may be due to less weed density in MTPR. Similarly herbicide treatments also showed significant variation with respect to growth components. Maximum pooled values as plant height $(93.5 \mathrm{~cm})$, no. of effective tillers (244.65), dry matter $\left(1370 \mathrm{~g} \mathrm{~m}^{-2}\right)$, panicle length $(24.85 \mathrm{~cm})$, weight of panicle $(2.68 \mathrm{~g})$, no. of grains per panicle (115.34) and test weight $(25.68 \mathrm{~g})$ was recorded in treatment $\mathrm{W}_{5}$ followed by treatment $\mathrm{W}_{6}$ which was found to be at par to treatment $\mathrm{W}_{5}$ in all growth parameters except dry matter accumulation $\mathrm{m}^{-2}$ this may be due to these herbicides belong to sulfonyl urease group which do not allow or rather kill the emerging weeds and the weed which escape from pyrazosulfuron are killed by bispyribac sodium which is applied 22 DAS. The other reason may be due to the fact that these herbicides are protein inhibitors thus not allowing the weed plants to synthesis protein 
and hence are killed. Irrigation water application was higher in transplanted rice than DSR. Direct seeded rice gave more water productivity than transplanted rice. Due to cracking in puddle transplanted rice irrigation water was required more and continuously.

An appraisal of table 3 shows significant variation with respect to tillage practice on grain and straw yield maximum pooled values of grain yield (3778 kg ha $\mathrm{kg}^{-1}$ ) and straw yield $\left(6105 \mathrm{~kg} \mathrm{ha}^{-1}\right)$ was recorded in treatment $\mathrm{T}_{3}$ (MTPR) followed by treatment $\mathrm{T}_{2}$ (ZTDSR) this may be due to higher and maximum yield attributes recorded under treatment $T_{3}$. Similarly herbicide treatments also showed significant variation with respect to grain and straw yield. Maximum pooled values of grain and straw yield were recorded as $3847 \mathrm{~kg} \mathrm{ha}^{-1}$ and $3694 \mathrm{~kg} \mathrm{ha}^{-1}$ respectively in treatment $\mathrm{W}_{5}$ followed by treatment $\mathrm{W}_{6}$. Further the table also revolved that among tillage practices maximum net return (Rs. 25831) and B: C ratio (1.93) was recorded in treatment $T_{3}$ followed by treatment $\mathrm{T}_{2}$ which recorded net return and $\mathrm{B}$ : $\mathrm{C}$ ratio as (Rs. 23626 ha-1) and 1.89) respectively. Among herbicidal treatment maximum net return and $\mathrm{B}$ : $\mathrm{C}$ ratio as (Rs 28631 and 2.05) was recorded in treatment $\mathrm{W}_{5}$ followed by treatment $\mathrm{W}_{6}(\mathrm{KP}$ Bhurer et al., 2013). This may be due to higher yield attributes resulting in higher grain and straw yield and lower cost of cultivation in treatment $T_{3}$ and followed by treatment $T_{2}$ than in conventional tillage $\mathrm{T}_{4}$ (Gill et al., 2014). The labour cost in conventional tillage was much higher and tillage practices $\mathrm{CT}$ also recorded maximum time there by resulting in higher cost on labour wages and fuel use for ploughing, puddling and irrigation, while less number of labours and minimum time of work by them led to low cost of cultivation in treatment $\mathrm{T}_{3}$ and treatment $T_{2}$. Similarly weeding by manual labour in conventional tillage resulted in more cost of cultivation than herbicidal treatments.

\section{References}

Anonymous, 2013. Area, production and yield of rice in India.
Anwar, M.P., Juraimi, A.S., Man, A., Puteh, A., Soimer, A. and Begum, M. 2010. Weed Suppressive ability of rice (Oryza sativa L.) germplasm under aerobic soil conditions. Australian J. Crop Sci. 4(9): 706-717.

Bhuren, K.P., Yadav, D.N., Ladha, J.K., Thapa, R.B. and Pandey, K.P. 2013. Effect of integrated weed management practices on performance of dry direct seeded rice (Oryza sativa L.). Agronomy J. Nepal (Agron JN) Vol. 3. 2013. 53.

Bouman, BAM. 2003. Examining the water shortage problem in rice system water saving irrigation technologies. In Proc. Inter Rice Res. Conference Bejing China, 16-19 September (2002) In Mew TW Btar DS Peng 5, Dawe D. Hardy B (cds) Rice Sci. Innovation and Impact for Livelihood pp. 519-533.

Bouman BAM., Wang, H., Yang, X., Zhoo, J. and Wong, C. 2002. Aerobic rice (Han Dao). A New way of growing rice in water shortage areas. In Proc. of the $12^{\text {th }}$ Inter Soil Conservation Organization Conference 2631 May (2002). Beijing. China Tainghua University Press pp 175-181.

Chauhan, B.S., and Opeña, J. 2012. Effect of tillage systems and herbicides on weed emergence, weed growth, and grain yield in dry-seeded rice systems. Field Crop Res 137:56-69. doi: 10.1016/j.fcr

Chauhan, B.S., Mahajan, G., Sardana, V., Timsina, J. and Jat, M.L., (2012). Productivity and sustainability of the ricewheat cropping system in the IndoGangetic Plains of the Indian subcontinent: problems, opportunities, and strategies. Adv. Agron. 117, 315-369

Chauhan, B.S., Prabhjyot-Kaur Mahajan, G., Randhawa, R.K., Singh, H., and Kang, M.S., (2014). Global warming and its possible impact on agriculture in India. Adv. Agron. 123, 65-121.

Gill, M. S., Kumar, A. and Kumar, P. (2006). Growth and yield of rice under various method and times of sowing. Indian J. Agron. 51: 123-27.

Ladha, J.K., Pathak, H., Padre, A.T., Dave, D., Gupta, R.K., 2003. Productivity trends in Intensive in rice-wheat cropping system in Asia. In: Ladha, J.K. (Ed.), Improving the 
Productivity and Sustainability of RiceWheat System: Issues and Impacts. ASA Special Publication No. 65, ASA, CSSA, and SSSA, Madison, WI, USA, pp. 45-76.

Gangwar, K. S., Sharma, Tomar, O. K. and Pandey, D. K. (2005). Effect of rice crop establishment methods on hybrid rice productivity in northwest India. International Rice Research Notes 30: 4243.

Gill, Jagjot Singh (2013). Studies on establishment methods, nitrogen requirement and foliar feeding of micronutrients on productivity of basmati rice (Oryza sativa L.). Ph.D. dissertation, Punjab Agricultural University, Ludhiana.

Gill, Jagiot Singh., Walia, Sohan Singh. And Gill, Roopinder Singh. 2014. Direct seeded rice: An Alternative rice establishment technique in north-west India - A review. International J. Advance Research, Volume 2 , Issue 3, 375-386.

Mahajan, G., Chauhan, B.S. and Gill, M.S., (2011). Optimal nitrogen fertilization timing and rate in dry-seeded rice in northwest India. Agron. J. 103, 1676-1682.

Mahajan, G., Chauhan, B.S., Timsina, J., Singh, P.P. and Singh, K., (2012). Crop performance and water and nitrogen-use efficiencies in dry-seeded rice in response to irrigation and fertilizer amounts in northwest India. Field Crops Res. 134, 5970.

Mahajan, G., Chauhan, B.S. and Gill, M.S., (2013). Dry-seeded rice culture in Punjab state of India: lessons learned from farmers. Field Crop. Res. 144, 89-99.

Mishra, J.S., Singh, V.P., 2011. Effect of tillage and weed control on weed dynamics, Crop productivity and energy-use efficiency in rice (Oryza sativa) - based cropping system in Vertisols. Indian J. Agri. Sci. 81, 129133.

Sharma, P.K., Bhushan, L., Ladha, J.K., Naresh, R.K., Gupta, R.K., Balasubramanian, B.V., and Bouman BAM (2002) Crop-water relations in rice-wheat cropping under different tillage systems practices in a marginally Water-wise rice production. International Rice Research Institute Los Banos, pp 223-235.

Sharma, S.N., Singh, R.K. 2010. Weed management in rice-wheat cropping system under conservation tillage. Indian J. Weed Science 42, 23-29.

Singh, G., Singh, Y., Singh, V.P., Johnson, D.E. and Mortimer, M. 2005a. System-level effects in weed management in rice-wheat system in India. In: Proceeding of the BCPC International Congress on Crop Science and Technology. The British Crop protection Council, Glasgow, Scotland, UK, pp. 545-550.

Singh, G. and Singh, O. P. (1993). Effect of method of seeding and level of nitrogen on yield and yield attributes of rice under flood-affected conditions. Indian J. Agron. 38: 551-54.

Singh, A.K., Choudhury, B.U. and Bouman, BAM. 2002. Effects of rice establishment methods On crop performance, water use, and mineral nitrogen. Water-wise rice production. International Rice Research Institute, Los Banos, pp 237-246.

Singh, A.K. and Chinnusamy, V. 2006. Aerobic Rice Prospects for Enhancing Water Productivity. In: Indian Farming. October (2006). Sinoquet H. Bonhomme R (1992). Modeling radiative transfer in mixed and row intercropping systems. Agric. For. Meteorol. 62: 219-240.

\section{How to cite this article:}

Singh, P.K., Manita Kumari, Pradeep Prasad and Rajiv Nayan. 2017. Impact of Different Tillage Practices with Weed Management Methods on Growth, Yield and Economics of Rice (Oryza sativa L.) in South Eastern Part of Bihar. Int.J.Curr.Microbiol.App.Sci. 6(7): 1665-1672. doi: https://doi.org/10.20546/ijcmas.2017.607.201 